\title{
Эффективность выращивания мини-клубней картофеля на современных установках в зависимости от генотипа
}

\author{
К.А. Колошина*, Н.И. Полухин, Г.Х. Мызгина \\ Сибирский научно-исследовательский институт растениеводства и селекции- \\ филиал ФИЦ Институт цитологии и генетики СО РАН, р.п. Краснообск, Россия \\ *e-mail: kristina.koloshina@yandex.ru
}

Новые технологические решения в области аэропоники позволили значительно усовершенствовать процесс получения мини-клубней как исходного материала для семеноводства картофеля.

Основные преимущества аэропонной технологии заключаются в том, что это безопасный и экологически чистый способ получения естественных здоровых клубней картофеля. Аэропонные установки позволяют выращивать миниклубни без зависимости от погодных и климатических условий внешней среды с укороченным сроком вегетации растений. Предлагаемый способ позволяет на ограниченных посадочных площадях выращивать большие количества растений, нежели в открытом грунте или в теплице, кроме того, отсутствие почвы исключает борьбу с соответствующими болезнями и вредителями и упрощает уход за растениями, значительно увеличивая коэффициент размножения.

Продолжительность вегетации растений в условиях аэропоники, по литературным данным, может составлять от четырех до восьми месяцев. За это период может быть получено в среднем 45 мини-клубней с одного растения. При традиционных методах выращивания одно растение дает от 6 до 10 мини-клубней в течение трехчетырех месяцев, и собираются они в один прием.

Цель работы - изучить сортовые особенности выращивания мини-клубней картофеля как исходного материала в семеноводстве на аэропонных установках.

Работа проводилась на одноярусной универсальной аэропонной установке конструкции ФГБНУ ВНИИСБ (Ю.Ц. Мартиросян) на питательном растворе представленным разработчиком. Выращивание мини-клубней проводилось на пяти сортах: Златка, Юна, Сокур, Сафо и Розара.

Сбор с одного растения в среднем по сортам составил 51 шт. Наиболее близко условия аэропоники подошли для сортов Сокур и Розара, урожай по этим сортам составил 73,2 и 72,7 шт. соответственно. Менее благоприятно они сказались на сортах Златка - 51,1 шт., Сафо - 33 шт., Юна - 25,2 шт. Поэтому дальнейшее совершенствование аэропонных технологий имеет обоснованные и реальные перспективы. 